ZOOLOGIA 30 (1): 1-14, February, 2013

http://dx.doi.org/10.1590/S1984-46702013000100001

\title{
Culicidae (Diptera: Culicomorpha) from the central Brazilian Amazon: Nhamundá and Abacaxis Rivers
}

\author{
Rosa Sá Gomes Hutchings', Roger William Hutchings ${ }^{1,3}$ Honegger \& Maria Anice Mureb Sallum² \\ ${ }^{1}$ Coordenação de Biodiversidade, Instituto Nacional de Pesquisas da Amazônia. Caixa Postal 2223 AC Andre Araujo, \\ 69080-971 Manaus, AM, Brazil. \\ 2 Laboratório de Sistemática e Ecologia de Culicidae, Faculdade de Saúde Pública, Universidade de São Paulo. \\ 01246-904 São Paulo, SP, Brazil. \\ ${ }^{3}$ Corresponding author. E-mail: rwhutch@inpa.gov.br
}

\begin{abstract}
Mosquito fauna (Culicidae) from remote areas along the geographical limits of the State of Amazonas were assessed by employing CDC, Shannon, Malaise and Suspended traps, together with net sweeping and immature collections. Two hundred and six collections were performed in seven localities along the Nhamundá and Abacaxis Rivers, State of Amazonas, Brazil, during May and June 2008. The northernmost locality was $120 \mathrm{~km}$ from Nhamundá, whereas the southernmost locality was $150 \mathrm{~km}$ from the mouth of the Abacaxis River. The 5,290 mosquitoes collected are distributed in 16 genera, representing 109 different species, of which eight are new distributional records for the State of Amazonas. Furthermore, there are nine morphospecies which may represent undescribed new taxa, five of which are also new records for the State of Amazonas. Culex presented the highest number of species and the largest number of individuals. Anopheles, which represents $3 \%$ of the total sample, had the second highest number of species, followed by Wyeomyia. Psorophora and Aedes, represent the third and fourth largest number of individuals. The most abundant species was $C x$. (Mel.) vaxus Dyar, 1920 followed by Cx. (Mel.) eknomios Forattini \& Sallum, 1992, Cx. (Cux.) mollis Dyar \& Knab, 1906, Cx. (Mel.) theobaldi Lutz, 1904, and CX. (Cux.) declarator Dyar \& Knab, 1906. The epidemiological and ecological implications of mosquito species found are discussed and are compared with other mosquito inventories from the Amazon region. The results presented represent the largest standardized inventory of mosquitoes of the Nhamundá and Abacaxis rivers, with the identification of 118 species level taxa distributed in seven localities, within four municipalities (Nhamundá, Maués, Borba, Nova Olinda do Norte), of which we have only few or no records in the published literature.
\end{abstract}

KEY WORDS. Amazonia; distribution; mosquitoes.

There are about 3,523 species of mosquitoes (Culicidae) described throughout the world (НАRBACH 2012). Mosquitoes have a worldwide distribution with at least 553 species present in the Neotropical region, of which 468 are recorded from Brazil (GAFFIGAN et al. 2012). Records of geographical distribution are essential to improve our knowledge of the systematics of mosquitoes, as well as the need for the correct identification of species in studies of biodiversity, ecology and vector incrimination. In general, the knowledge of the biodiversity of Culicidae is of public health interest, since it enables a better understanding of the dynamics of transmission of infectious agents and the role of mosquito species as vectors, facilitating the adoption of control measures.

Because of its extensive and complex geographical structure, the Amazon region has many remote areas, such as the basins of the Nhamundá and Abacaxis rivers, located north and south of the Amazon River along the eastern border of the Brazilian State of Amazonas, where the Culicidae fauna is un- known. Unfortunately, very little is known about the geographic distribution of mosquitoes in the State of Amazonas. CERQUeIRA (1961), in a pioneering work, using information gathered from the collections of the defunct Serviço Nacional de Febre Amarela (National Yellow Fever Service) and material collected by the Instituto Nacional de Pesquisas da Amazônia (National Institute of Amazonian Research), reported the presence of 148 species in 24 locations within the State of Amazonas. Later, several papers were published on the geographical distribution of $\mathrm{Cu}$ licidae in the Amazon, using information gathered from bibliographical references and material from the Entomology Museum of the Centro de Pesquisas René Rachou (FIOCRUZ) (René Rachou Research Center), adding new locality records for the state, where the number of known species increased to 175 in 114 locations representing $61 \%$ of the state's municipalities (Xavier \& Mattos 1976). Unfortunately, after Xavier \& Mattos (1976), there has not been any new publication compiling and updating the distribution records of species which can be found 
in more recent publications. Most of these new records of distribution are found in publications resulting from inventories (Barbosa et al. 2008, Hutchings et al. 2002, 2005, 2008, 2010, 2011, SuÁrez-Mutis et al. 2009) and as a result of the description of new species (Forattini \& Sallum 1992, Sallum \& Hutchings 2003, SALLUM et al. 1997).

It should be noted that many of the published records are not results of collections made with the purpose of studying the entire mosquito community, but mainly had epidemiological objectives (Cerqueira 1961, Deane 1947). Therefore, any list of species prepared for a given location which is based on published records may be incomplete and/or biased. For example, after collecting 119 species in the Jau National Park, $25 \%$ (30 species) were new records for the State of Amazonas (Hutchings et al. 2005) and of 145 species collected north of Manaus (Hutchings et al. 2011), 16\% (23 species) are also new records for the State of Amazonas, including seven new records for Brazil. Outside of being biased, the geographical distribution of published records is still unrepresentative given the low coverage of the municipalities. Although the coverage includes $61 \%$ of the municipalities within the State of Amazonas, the sampled area of each municipality is still very small.

It is important to consider that an increase in the knowledge of the mosquito fauna of the Amazon region will permit us to obtain basic information of the faunal diversity, distribution and variety of ecosystems where mosquitoes occur, thus providing basic knowledge for studies on the control of diseases which affect humans and animals, whose infectious agents are transmitted by mosquitoes. In this work, we present the first results of mosquito collections from remote regions lo- cated near the political boundaries of the State of Amazonas, as part of the project "Amazonas: Diversidade de insetos ao longo de suas fronteiras" of the Programa de Apoio a Núcleos de Excelência (FAPEAM-CNPq).

Therefore, with the objective of serving as a base inventory for future surveys of Culicidae from the Amazon, the mosquito species collected inside the riparian and terra firme forests along the basins of the Nhamundá and Abacaxis rivers, Amazonas, Brazil, are reported herein.

\section{MATERIAL AND METHODS}

A mosquito inventory, conducted during a river expedition in areas near the eastern border of the State of Amazonas, Brazil (Fig. 1), includes collections of mosquitoes from seven different localities: two localities along the Nhamundá River, Municipality of Nhamundá (between $01^{\circ} 35^{\prime} \mathrm{S}, 057^{\circ} 37^{\prime} \mathrm{W}$ and $\left.01^{\circ} 53^{\prime} \mathrm{S}, 057^{\circ} 03^{\prime} \mathrm{W}\right)$; and five localities along the Abacaxis River, including the Municipalities of Maués, Borba and Nova Olinda do Norte (between $05^{\circ} 15^{\prime} \mathrm{S}, 058^{\circ} 41^{\prime} \mathrm{W}$ and $04^{\circ} 28^{\prime} \mathrm{S}, 058^{\circ} 33^{\prime} \mathrm{W}$ ). These localities are characterized by having most of their area covered by dense upland (terra firme) ombrophilous forests with low plateaus, together with riparian rain forests having dense alluvial and lowland vegetation (Floresta Ombrófila Densa Aluvial e de Terras Baixas) along the rivers, intermixed with areas of transition including Amazonian white sand (campinarana) and floodplain (varzea) forests. The tropical rainforest climate is warm and wet, characterized by being constantly humid, with temperature and precipitation with little annual variation. Based on climatic data from Parintins and Maues (RADAMBRASIL 1976), the

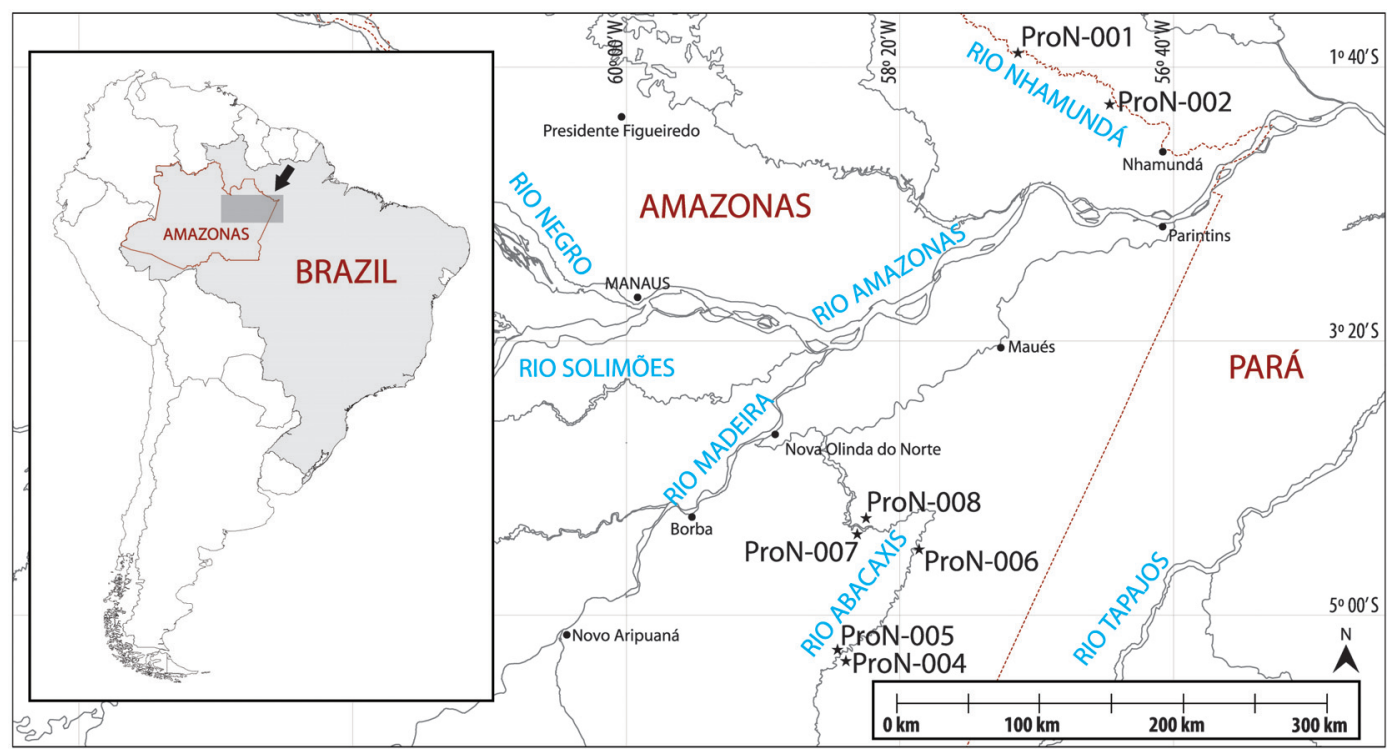

Figure 1. Localities sampled along the Nhamundá and Abacaxis Rivers, State of Amazonas, Brazil (The stars indicate the collecting locations described in Table I).

ZOOLOGIA 30 (1): 1-14, February, 2013 
region has an annual relative humidity of $86 \%$ and a mean annual temperature of $26^{\circ} \mathrm{C}$. A shorter dry season occurs from July to November with the lowest monthly precipitation being less than $50 \mathrm{~mm}$ along the Nhamundá River and over $150 \mathrm{~mm}$ along the Abacaxis River. The rainy season occurs between December and June, with the maximum precipitation in April. For the Nhamundá basin the mean annual precipitation is $1,750 \mathrm{~mm}$, while the Abacaxis basin is greater than $2,750 \mathrm{~mm}$.

Located in the far eastern region of the State of Amazonas, there are many difficulties in accessing the collection locations because of the long distance from urban centers. The most remote locality surveyed along the Nhamundá River is $240 \mathrm{~km}$ from Parintins and $630 \mathrm{~km}$ from Manaus, while the localities along the Abacaxis River are $360 \mathrm{~km}$ from Maués and $530 \mathrm{~km}$ from Manaus. The region, with a very low demographic density, only has small settlements which occupy marginal areas along the rivers. The main means of transport is by boat.

Mosquitoes specimens were mostly collected inside the riparian forest along existing and/or newly created trails, perpendicular to the river banks, and within continuous upland terra firme forest using a variety of capture methods including: CDC traps with different types of lighting (incandescent lamp (CDC) or ultraviolet fluorescent tube (UV CDC)); flight intercept traps (Malaise, Shannon, Suspended); and sweeping with nets. The CDC traps were installed every $50 \mathrm{~m}$ along trails, placed at 1, 10, 15 or $20 \mathrm{~m}$ above the ground, and were activated at dusk for a period of 12 hours, between 18:00 and 06:00 h. The Shannon traps, placed within small open understory areas, using an internal light source for attraction and a portable battery powered aspirator for capturing specimens, were used between 18:00 and 21:00 h. The $6 \mathrm{~m}$ long Malaise flight intercept traps, also placed within small open understory areas, were used for periods of up to three days and the Suspended flight intercept traps were hung one meter above the water level, along river margins, or at tree canopy level, also for periods of up to three days. Each sweeping collection, using entomological nets, was performed during a minimum of two hours at each location. Immature mosquitoes were collected from breeding sites found along trails, in the same areas where adults were captured. The immature mosquitoes were reared for the purpose of obtaining adult males and females, associated with larval and pupal exuviae. These reared specimens were mostly used to obtain a more accurate identification of adult female specimens captured using other methods.

Adult and immature mosquitoes were captured, preserved and mounted following techniques detailed by BELKIN et al. (1967). Specimens were identified in the laboratories at INPA in Manaus, and were confirmed at the Laboratório de Sistemática e Ecologia de Culicidae (LASEC), of the Faculdade de Saúde Pública (FSP/USP), in São Paulo and in the Laboratório de Transmissores de Hematozoários of the Instituto Oswaldo Cruz (IOC), in Rio de Janeiro, using the identification keys in LANe (1953a, b), Forattini (1965a, b, 2002), Zavortink (1972, 1979), Arnell (1973), Valencia (1973), Berlin \& Belkin (1980), Sallum \& Forattini (1996), as well as the Pecor et al. (1992) cata$\log$ for Culex (Melanoconion). Whenever possible, anatomical characteristics of the male genitalia were examined to confirm the identifications of both females and males. The collected material will be deposited in the Coleção de Invertebrados of the Instituto Nacional de Pesquisas da Amazônia (INPAManaus), in the Coleção Entomológica de Referência of the Faculdade de Saúde Pública, Universidade de São Paulo (FSP/ USP) and in the Coleção de Culicídeos of the Instituto Oswaldo Cruz (FIOCRUZ). The collection and specimen data was digitized, stored, archived and organized using the relational database structure provided by the Biota software version 2.04 (Colwell 2012).

\section{RESULTS}

A total of 206 collections distributed in seven locations along the Nhamundá and Abacaxis Rivers, in the State of Amazonas, from May 14 to June 6, 2008, resulted in the capture of over 5,000 mosquitoes (Table I). Each collection corresponds to the capture yield of a trap (i.e. CDC, CDC UV, Shannon, Malaise, and Suspended) or method (i.e. sweeping,

Table I. Collections of mosquitoes distributed in seven localities along the Nhamundá and Abacaxis Rivers in the State of Amazonas, Brazil.

\begin{tabular}{|c|c|c|c|c|c|}
\hline Locality & Locality name* & Municipality & Coordinates & $\begin{array}{l}\text { Number of } \\
\text { collections }\end{array}$ & $\begin{array}{l}\text { Number of } \\
\text { specimens }\end{array}$ \\
\hline ProN-001 & Areia, Igarape do Areia (LM), Rio Nhamundá (RM) & Nhamundá & $01^{\circ} 35^{\prime} 22^{\prime \prime} \mathrm{S}, 57^{\circ} 37^{\prime} 06^{\prime \prime} \mathrm{W}$ & 55 & 674 \\
\hline ProN-002 & Cuipiranga, Lago do Aburi, Rio Nhamundá (RM) & Nhamundá & $01^{\circ} 53^{\prime} 42^{\prime \prime} \mathrm{S}, 57^{\circ} 03^{\prime} 25^{\prime \prime} \mathrm{W}$ & 43 & 259 \\
\hline ProN-004 & Picada Pirarara, Rio Abacaxis (RM) & Maues & $05^{\circ} 15^{\prime} 09^{\prime \prime} \mathrm{S}, 58^{\circ} 41^{\prime} 52^{\prime \prime} \mathrm{W}$ & 26 & 512 \\
\hline ProN-005 & Picada Borba, Rio Abacaxis (LM) & Borba & $05^{\circ} 13^{\prime} 19^{\prime \prime} \mathrm{S}, 58^{\circ} 41^{\prime} 22^{\prime \prime} \mathrm{W}$ & 20 & 659 \\
\hline ProN-006 & Pacamiri, Rio Abacaxis (RM) & Maues & $04^{\circ} 35^{\prime} 49^{\prime \prime} \mathrm{S}, 58^{\circ} 13^{\prime} 14^{\prime \prime} \mathrm{W}$ & 29 & 1,118 \\
\hline ProN-007 & Paxiuba, Rio Abacaxis (LM) & Borba & $04^{\circ} 29^{\prime} 00^{\prime \prime} \mathrm{S}, 58^{\circ} 34^{\prime} 14^{\prime \prime} \mathrm{W}$ & 32 & 2,044 \\
\hline ProN-008 & Paxiuba, Rio Abacaxis (RM) & Nova Olinda do Norte & $04^{\circ} 28^{\prime} 36^{\prime \prime} \mathrm{S}, 58^{\circ} 33^{\prime} 46^{\prime \prime} \mathrm{W}$ & 1 & 24 \\
\hline Total & & & & 206 & 5,290 \\
\hline
\end{tabular}


immature rearing) (Table II). The CDC traps were used during 1,200 trap-hours and the CDC UV during 744 trap-hours. The Shannon traps were used in eight collections, totaling 28 traphours. The $6 \mathrm{~m}$ Malaise flight intercept traps were used during 15 trap-days and the Suspended traps during nine trap-days. The net sweeping collections were done during 40 hours. A total of eight immature collections were performed in different habitats: Bromeliaceae leaf axils (three samples); lakes and streams (3); in a tree hole; and in a Bertholletia pixidium. More specific information on the sampling effort for each locality is presented in Table II.

Of the 5,290 specimens captured, 5,231 were identified and are distributed in 16 genera, representing 118 different taxa (among species and morphospecies) (Appendix 1). The morphospecies (identified as near $\mathrm{F \# )} \mathrm{are} \mathrm{similar} \mathrm{to} \mathrm{a} \mathrm{known}$ species, but it is believed that some may represent undescribed new taxa. Some identification could not be exact because of the absence of males, whose genitalia usually possess anatomical features that allow the specific diagnosis. These individuals were identified as morphotypes, indicating the species to which they are most similar.

Unfortunately, among the mounted, sorted and examined material, it was not possible to identify 1,815 specimens $(\approx 34 \%)$ to the species level for several reasons: either there are no known characters to separate female individuals of different species or the characters used to separate these species were damaged. For some of these individuals it was only possible to identify to ge- nus level because the characters which are used for identification are damaged and/or lost, and the rest of the collected material was recognized to subgeneric or informal taxonomic group (sections or groups) level (shown with the prefix "gr.", "sG." or "sec." or the suffix "sp." in Appendix 1). Most of the individuals that could not be identified to species level are females $\left(1790 \mathrm{H}^{\prime}\right.$ 98\%) and belong to the genus Culex (91\%) (Appendix 1). It is interesting to note that only $13 \%$ of the specimens collected in this inventory were males.

Culex presented the highest number of species $\left(45 \mathrm{H}^{\prime \prime}\right.$ $42 \%)$ and the largest number of individuals (4,653 H" 89\%). The genus Anopheles, which represents $3 \%$ of the total sample (166 specimens), had the second highest number of species (13 H" 12\%), followed by Wyeomyia with 11 species ( $\left.\mathrm{H}^{\prime \prime} 10 \%\right)$, and less than $1 \%$ of individuals. Psorophora and Aedes, respectively with 9 and 8 species each $\left(\mathrm{H}^{\prime \prime} 7 \%\right)$, represent the third largest $\left(178 \mathrm{H}^{\prime \prime} 3 \%\right)$ and the fourth largest number of individuals $(90<2 \%)$.

The most abundant species was Culex (Mel.) vaxus Dyar, 1920 (587 individuals collected, representing 17\% of the material identified to species level) followed by $\mathrm{Cx}$. (Mel.) eknomios Forattini \& Sallum, 1992, Cx. (Cux.) mollis Dyar \& Knab, 1906, Cx. (Mel.) theobaldi Lutz, 1904, and Cx. (Cux.) declarator Dyar \& Knab, 1906 (with 481, 456, 415 and 255 individuals, respectively). The five most abundant species $(<5 \%$ of the recorded species) represent $66 \%$ of specimens identified to the species level.

Table II. Method of capture, sampling effort and number of mosquitoes collected along the Nhamundá and Abacaxis Rivers in the State of Amazonas, Brazil.

\begin{tabular}{|c|c|c|c|c|}
\hline \multirow[t]{2}{*}{ Method of capture } & \multirow{2}{*}{$\begin{array}{l}\text { Species/Method } \\
\text { Total number } \\
\text { Exclusive number }\end{array}$} & \multicolumn{3}{|c|}{$\begin{array}{l}\text { Number of specimens } \\
\text { Sampling effort }\end{array}$} \\
\hline & & Total & Nhamundá River & Abacaxis River \\
\hline \multirow[t]{2}{*}{ CDC trap } & 51 & 2,573 & 152 & 2,421 \\
\hline & 7 & $100 \mathrm{c}: 1,200 \mathrm{~h}$ & $44 c: 528 h$ & $56 c: 672 h$ \\
\hline \multirow[t]{2}{*}{ CDC (UV) trap } & 62 & 1,777 & 299 & 1478 \\
\hline & 12 & $62 c: 744 h$ & $34 c: 408 h$ & $28 c: 336 h$ \\
\hline \multirow[t]{2}{*}{ Shannon Trap } & 31 & 406 & 155 & 251 \\
\hline & 3 & $8 c: 28 h$ & $5 c: 17 h$ & $3 c: 11 \mathrm{~h}$ \\
\hline \multirow[t]{2}{*}{ Net sweeping } & 51 & 376 & 219 & 157 \\
\hline & 17 & $20 c: 40 h$ & $9 c: 18 h$ & $11 c: 22 h$ \\
\hline \multirow[t]{2}{*}{ Malaise Trap } & 18 & 56 & 41 & 15 \\
\hline & 4 & $5 c: 15 d$ & $3 c: 9 d$ & $2 c: 6 d$ \\
\hline \multirow[t]{2}{*}{ Suspended Trap } & 18 & 69 & 48 & 21 \\
\hline & 6 & $3 c: 6 d$ & $1 c: 3 d$ & $2 c: 3 d$ \\
\hline \multirow[t]{2}{*}{ Immature collections } & 9 & 33 & 19 & 14 \\
\hline & 4 & $8 c$ & $2 c$ & $6 c$ \\
\hline \multirow{2}{*}{ Total } & 118 & 5,290 & 933 & 4,357 \\
\hline & 53 & $206 c$ & $98 c$ & $108 \mathrm{c}$ \\
\hline
\end{tabular}

The values in italics indicate the sampling effort for the method used: number of collections (\#c); trap-hours (\#h); or trap-days (\#d). 
Among the 110 species identified, there are eight new species distribution records for the State of Amazonas: Psorophora (Jan.) discrucians (Walker, 1856); Culex (And.) luteopleurus (Theobald, 1903); Culex (Mel.) rooti Rozeboom, 1935; Culex (Mel.) trigeminatus Clastrier, 1970; Culex (Mcx.) aureus Lane \& Whitman, 1951; Onirion brucei (Del Ponte \& Cerqueira, 1938); Wyeomyia (Spi.) aningae Motta \& Lourenço, 2005; and Wyeomyia surinamensis Bruijning, 1959. There are also 203 specimens of at least nine morphospecies (marked as near F \# in Appendix 1), of which five also represent new geographical records for the State of Amazonas. These morphospecies, which probably represent species not yet described, belong to three different genera. Aedes (Ochlerotatus) has a total of four specimens of two morphotypes: Ae. (Och.) near pectinatus F1 and Ae. (Och.) near sG Infirmatus F1. Culex (Melanoconion) has 196 specimens of six morphotypes: Cx. (Mel.) near creole F1, Cx. (Mel.) near eastor F1, Cx. (Mel.) near silvai F1, Cx. (Mel.) near vaxus F1, Cx. (Mel.) near vaxus F3 and CX. (Mel.) near venezuelensis F1. Wyeomyia (Hystatomyia) has two specimens of one morphotype: $W y$. (Hys.) near baltae F1. Among the nine morphotypes identified (Anopheles (Nys.) goeldi/ dunhami, Anopheles (Nys.) konderi/oswaldoi, Anopheles (Ste.) nimbus/thomasi, Aedes (Och.) hastatus/oligopistus, Aedes (Och.) serratus/nubilus, Culex (Ads.) clastrieri/guyanensis, Culex (Car.) urichii/ anduzei, Culex (Cux.) coronator/usquatus and Culex (Cux.) mollis/declarator) there are seven species (indicated in bold above) which could potentially also increase the number of species recorded within each sampled locality.

Together, the nocturnal collecting methods (CDC, CDCUV and Shannon Traps) were responsible for $90 \%$ of the captured mosquitoes, of which the CDC traps (with a total combined sampling effort of 162 trap-nights) were responsible for more than $83 \%$. Net sweeping accounted for $7 \%$, followed by the Suspended and Malaise flight intercept traps, with $1.3 \%$ and $1 \%$ of the specimens, respectively (Table II). Both types of CDC traps together were responsible for collecting $62 \%$ (73) of the species level taxa, of which the CDC-UV trap alone collected $53 \%$ of the species level taxa. The adult specimens of Aedeomyia, Orthopodomyia and Uranotaenia were only collected at night (CDC, CDC-UV and Shannon), while Haemagogus was only collected during the day and Onirion was only registered by rearing larvae. The methods of capture for each taxon can be seen in the final columns of Appendix 1. Net sweeping, and the CDC type traps combined, were responsible for the highest number of species which were only and exclusively collected with a specific method of capture, although every method did collect exclusive species (see details in Table II). The diurnal mosquitoes are not equally represented in this inventory, compared to the nocturnal mosquitoes because the sampling effort was greater for the nocturnal collecting methods.

Of the 118 different species level taxa identified during this inventory, $48(41 \%)$ were collected in both river basins, while 29 species (24\%) were found only along the Nhamundá River and 41 species (35\%) were only found along the Abacaxis
River (Appendix 1). The results of the mosquito inventory for each separate river basin are presented below.

\section{Nhamundá River}

The inventory along the Nhamundá river basin, sampled from May 16 to 19, includes specimens from 98 collections in two localities (Table I), resulting in 933 mosquitoes from 15 genera, representing 77 different taxa identified to species level (between species and morphospecies) (Appendix 1). It was not possible to identify 256 specimens ( $\mathrm{H}^{\prime \prime} 27 \%$ ) to the species level for the reasons previously discussed. For this basin, the sampling effort included 528 CDC trap-hours, 408 CDC (UV) traphours, 17 Shannon trap-hours, 9 Malaise trap-days, 3 Suspended trap-days, 18 net sweeping hours and two immature collections (in a Bertholletia pixidium and a Bromeliaceae leaf axil) (Table II).

In the Nhamundá River basin, the genus Culex presented the highest number of species $\left(26 \mathrm{H}^{\prime \prime} 38 \%\right)$ and the largest number of individuals (712 $\mathrm{H}^{\prime \prime} 77 \%$ ). The genus Wyeomyia, which represents $4 \%$ of the total sample (34 specimens), had the second highest number of species $\left(11 \mathrm{H}^{\prime \prime} 16 \%\right)$, followed by Psorophora with only seven species represents the second largest number of specimens $\left(71 \mathrm{H}^{\prime \prime} 8 \%\right)$. Anopheles had 6 species ( $\left.\mathrm{H}^{\prime \prime} 9 \%\right)$, and less than $4 \%$ of the individuals, while Aedes with five species had the third largest number of individuals $(45<5 \%)$. The most abundant taxon was the morphospecies Culex (Mel.) near vaxus F3 (142 individuals collected, representing 23\% of the specimens identified to species level) followed by Cx. (Mel.) vaxus Dyar, 1920, Cx. (Mel.) bequaerti Dyar \& Shannon, 1925, Psorophora (Jan.) ferox (Humboldt, 1819), and Cx. (Cux.) mollis Dyar \& Knab, 1906 (with 122, 64, 38 and 29 individuals, respectively). The five most abundant species $(<7 \%$ of the recorded species) represent $64 \%$ of specimens identified to the species level.

Among the 70 species, collected along the Nhamundá River, there are six new species distribution records for the state of Amazonas. There are also 159 specimens of at least seven morphospecies ( $9 \%$ of the species level taxa), of which four represent new geographical records for the State of Amazonas. These morphospecies, which probably represent species not yet described, belong to three different genera: Ae. (Och.) near sG Infirmatus F1, Cx. (Mel.) near creole F1, Cx. (Mel.) near silvai F1, Cx. (Mel.) near vaxus F1, Cx. (Mel.) near vaxus F3, Cx. (Mel.) near venezuelensis $\mathrm{F} 1$ and $W y$. (Hys.) near baltae F1.

\section{Abacaxis River}

The inventory along the Abacaxis river basin, sampled from May 26 to June 4, includes specimens from 108 collections in five localities (Table I), resulting in 4,357 mosquitoes, from 15 genera, representing 89 different taxa identified to species level (including species and morphospecies) (Appendix 1). It was not possible to identify 1558 specimens $\left(\mathrm{H}^{\prime \prime} 36 \%\right)$ to the species level for the reasons previously discussed. For this basin, the sampling effort included 672 CDC trap-hours, 336 
CDC (UV) trap-hours, 11 Shannon trap-hours, six Malaise trapdays, three Suspended trap-days, 22 net sweeping hours and six immature collections (in lakes and streams (three samples), in two Bromeliaceae leaf axils, and in a tree hole (Table II).

In the Abacaxis River basin, Culex presented the highest number of species $\left(37 \mathrm{H}^{\prime \prime} 44 \%\right)$ and the largest number of individuals (3,941 $\left.\mathrm{H}^{\prime \prime} 92 \%\right)$. Anopheles, which represents $3 \%$ of the total sample (136 specimens), had the second highest number of species (13 H" 15\%), followed by Psorophora and Aedes with six species $\left(\mathrm{H}^{\prime \prime} 7 \%\right)$ each, representing the third largest $\left(107 \mathrm{H}^{\prime \prime}\right.$ $3 \%)$ and the fourth largest number of individuals ( $45=1 \%)$. The most abundant species was $C x$. (Mel.) eknomios Forattini \& Sallum, 1992 (479 individuals collected, representing 18\% of the material identified to species level) followed by Culex (Mel.) vaxus Dyar, 1920, Cx. (Cux.) mollis Dyar \& Knab, 1906, Cx. (Mel.) theobaldi Lutz, 1904, and Cx. (Cux.) declarator Dyar \& Knab, 1906 (with 465, 427, 392 and 245 individuals, respectively). The five most abundant species ( $<6 \%$ of the recorded species) represent $74 \%$ of specimens identified to the species level.

Among the 84 species, collected along the Abacaxis River, there are three new species distribution records for the State of Amazonas. There are also 43 specimens of at least five morphospecies ( $\mathrm{H}^{\prime \prime} 6 \%$ ), of which two represent new geographical records for the State of Amazonas. These morphospecies, which probably represent species not yet described, belong to two different genera: Ae. (Och.) near pectinatus F1, Cx. (Mel.) near eastor F1, Cx. (Mel.) near silvai F1, Cx. (Mel.) near vaxus F1, and $\mathrm{Cx}$. (Mel.) near vaxus F3.

\section{DISCUSSION}

Among the 118 species level taxa collected in this inventory, there are 13 (11\%) new geographical distribution records for the State of Amazonas. Other mosquito surveys from upland terra firme sites have similar results: of the 145 species collected, north of Manaus, 16\% (23 species) were new records for the State of Amazonas (Hutchings et al. 2011); of the 119 species collected in the Jau National Park, 25\% (30 species) were new records (Hutchings et al. 2005); and of the 44 species recorded in Querari, 27\% (12 species) were also new records for the state (Hutchings et al. 2002). We found no previously published mosquito distributional records for the municipalities of Nhamundá and Nova Olinda do Norte. Therefore, the results of this inventory represent the first published report of mosquito taxa for these municipalities.

Epidemiologically, the presence of Anophelines may be important because this genus includes Plasmodium vector species, which cause malaria in humans. Within the Anopheles, it is worth noting the presence of Anopheles (Nys.) konderi s.l., An. (Nys.) oswaldoi s.l. and Anopheles (Nys.) triannulatus, and absence of An. (Nys.) darlingi Root, 1926 and any species of the An. (Nys.) albitarsis complex. Anopheles (Nys.) konderi s.l., An. (Nys.) oswaldoi s.l. and Anopheles (Nys.) triannulatus are consid- ered secondary vectors, but they can take the role of local or regional primary vectors (ForATTINI 2002). Considering that Anopheles (Nys.) konderi s.l. and An. (Nys.) oswaldoi s.l. were demonstrated to be species complexes (Мотокі et al. 2009, SAlLum et al. 2008), the vector status of each species needs to be determined in further studies conducted in areas of malaria transmission where species of these complexes are present. Additionally, the absence of An. (Nys.) darlingi and also of species of the An. (Nys.) albitarsis complex may be indicative of an undisturbed natural environment. In several studies conducted inside pristine areas of the State of Amazonas, no specimens of An. (Nys.) albitarsis s.l. and only a few specimens of An. (Nys.) darlingi were found. For example, only seven An. (Nys.) darlingi specimens ( $2 \%$ and $4 \%$ of the Anophelines, respectively) were collected in both the Jau National Park (Hutchings et al. 2005) and in the Juami-Japura Ecological Station (Hutchings et al. 2010), while only one $A n$. (Nys.) darlingi specimen (<0.4\%) was found in areas north of Manaus (Hutchings et al. 2011). In contrast, An. (Nys.) darlingi can be the most prevalent species inside deforested areas of the Amazon region (CASTro et al. 2006), whereas species of $A n$. (Nys.) albitarsis complex can become more frequent depending on the land use (ConN et al. 2002).

Furthermore, there are Culex species which are potential vectors of arboviruses. For example, $C x$. gnomatos, the second most common Culex species in these samples, is highly susceptible to infection by enzootic (ID and IE) and epizootic strains (IAB and IC) of the Venezuelan Equine Encephalitis Virus (VEEV) (Turell et al. 2000). It is worth mentioning that $C x$. pedroi, also a common species in these collections, is considered a potential enzootic vector of the Eastern Equine Encephalitis Virus (EEEV), in Brazil, as well as of the VEEV and other arboviruses (Galindo \& SRinongse 1967, Galindo et al. 1966, SRIHONGSE \& Galindo 1967). Moreover, it is interesting to note that AITKEN (1972) observed that Cx. portesi may be involved in the of epizootic and enzootic transmission cycles of the Mucambo virus. Cx. spissipes is a potential vector of the Bimiti, Caraparu, Oriboca and Itaqui viruses, of the Bunyaviridae family and of the VEEV III-B subtype (Shope et al. 1988, WAlton \& Grayson 1988).

Considering the number of specimens and/or species resulting from the different methods of capture and sampling efforts of this inventory (Table II), future mosquito surveys should give priority to the use of CDC type traps and net sweeping in order to maximize collecting results, when time and field resources are limited.

This mosquito inventory is part of a larger entomological inventory of different locations within remote and sparsely populated areas near the border regions of the State of Amazonas which also resulted in the collection of a large number of other insects, including Lepidoptera (CASAGRANDE et al. 2012). The information presented here represents the largest standardized mosquito inventory ever executed, within the Nhamundá and Abacaxis river basins, with the identification 
of 118 taxa distributed in seven different locations within four different counties (Nhamundá, Maués, Borba, Nova Olinda do Norte), of which few or no geographical records have been previously published.

\section{ACKNOWLEDGMENTS}

We wish to thank Monique de A. Motta (FIOCRUZ-RJ) for help with the identification of the Wyeomyia and the technicians, Luis Aquino, Jose M. da S. Vilhena, and Isis S. Menezes, for their help collecting and processing specimens. All specimens were collected using the "Autorização para Atividades com Finalidade Científica" (IBAMA/ICMBio/SISBIO) \#103281 (Roger W.H. Honegger). This research was financed with resources from the Fundação de Amparo à Pesquisa do Estado do Amazonas (FAPEAM) and the Conselho Nacional de Desenvolvimento Técnico e Científico (CNPq) through the project "Amazonas: diversidade de insetos ao longo de suas fronteiras" (Programa de Apoio a Núcleos de Excelência (PRONEX) Grant 1437/2007 coordinated by José A. Rafael) and from the Instituto Nacional de Pesquisas da Amazônia (INPA-PRJ12.10 Entomologia na Amazônia: Diversidade de insetos (2008/2012). Maria A.M. Sallum was financially supported by the Fundação de Amparo à Pesquisa do Estado de São Paulo (FAPESP) (Grant \#2011/203977) and the CNPq (BPP, Grant \#301666/2011-3).

\section{LITERATURE CITED}

AitKen, T.H.G. 1972. Habits of some mosquito hosts of VEE (Mucambo) virus from northeastern South America, including Trinidad, p. 254-256. In: Proceedings of the Workshop Symposium on Venezuelan Encephalitis Virus. Washington, D.C., Pan American Health Organization (PAHO) Scientific Publ., vol. 243.

Arnell, J.H. 1973. Mosquito Studies (Diptera, Culicidae). 32. A revision of the genus Haemagogus. Contributions of the American Entomological Institute 10 (2): 1-174.

Barbosa, M.D.G.V.; N.F. FÉ; A.H.R. Marcião; A.P.T.D. Silva; W.M. Monteiro; M.V.D.F. Guerra \& J.A.D.O. Guerra. 2008. Registro de Culicidae de importância epidemiológica na área rural de Manaus, Amazonas. Revista da Sociedade Brasileira de Medicina Tropical 41 (6): 658-663. doi: 10.1590/S003786822008000600019.

Belkin, J.N.; C.L. Hogue; P. Galindo; T.H. Aitken; R.X. Schick \& W.A. Powder. 1967. Estudios Sobre Mosquitos (Diptera, Culicidae) Ia. Un proyecto para un estudio sistematico de los mosquitos de Meso-America. IIa. Metodos para coleccionar, criar y preservar mosquitos. Contributions of the American Entomological Institute 1 (2a): 1-89.

Berlin, O.G.W. \& J.N. Belkin. 1980. Mosquito Studies (Diptera, Culicidae). 36. Subgenera Aedinus, Tinolestes and Anoedioporpa of Culex. Contributions of the American Entomological Institute 17 (2): 1-104.
Casagrande, M.M.; O.H.H. Mielke; E. Carneiro; J.A. Rafael \& R.W. Hutchings. 2012. Hesperioidea e Papilionoidea (Lepidoptera) coligidos em expedição aos Rios Nhamundá e Abacaxis, Amazonas, Brasil: novos subsídios para o conhecimento da biodiversidade da Amazônia Brasileira. Revista Brasileira de Entomologia 56 (1): 23-28. doi: 10.1590/S008556262012005000012.

Castro, M.C.D.; R.L. Monte-Mór; D.O. Sawyer \& B.H. Singer. 2006. Malaria risk on the Amazon frontier. Proceedings of the National Academy of Sciences 103 (7): 2452-2457. doi: 10.1073/pnas.0510576103.

Cerqueira, N.L. 1961. Distribuição geográfica dos mosquitos da Amazônia (Diptera, Culicidae, Culicinae). Revista Brasileira de Entomologia 10: 111-168.

CoLwell, R.K. 2012. Biota: The biodiversity database manager. Version 2.04. Storrs, University of Connecticut [Originally Published by Sinauer Associates, Sunderland, Massachusetts]. User's Guide and application. Avalaible online at: http:// viceroy.eeb.uconn.edu/Biota/ [Accessed: 11/VIII/2012]

Conn, J.E.; R.C. Wilkerson; M.N.O. Segura; R.T.L. de Souza; C.D. Schlichting; R.A. Wirtz \& M.M. PóvoA. 2002. Emergence of a new Neotropical malaria vector facilitated by human migration and changes in land use. American Journal of Tropical Medicine and Hygiene 66 (1): 18-22.

Deane, L.M. 1947. Observações sôbre a malária na Amazônia brasileira. Revista do Serviço Especial de Saúde Pública MES 1 (1): 3-59.

Forattini, O.P. 1965a. Entomologia Médica: Culicini - Culex, Aedes, Psorophora. São Paulo, Editora Universidade de São Paulo, vol. 2, 506p.

Forattini, O.P. 1965b. Entomologia Médica: Culicini Haemagogus, Mansonia, Culiseta, Sabethini, Toxorhynchitini, Arboviroses, Filariose Bancroftiana, Genética. São Paulo, Editora Universidade de São Paulo,vol. 3, 416p.

ForatTini, O.P. 2002. Culicidologia Médica: Identificação, Biologia, Epidemiologia. São Paulo, Editora Universidade de São Paulo,vol. 2, 860p.

Forattini, O.P. \& M.A.M. Sallum. 1992. A new species of Culex (Melanoconion) from the Amazonian region (Diptera: Culicidae). Memórias do Instituto Oswaldo Cruz 87 (2): 265-274. doi: 10.1590/S0074-02761992000200015.

Gaffigan, T.V.; R.C. Wilkerson; J.E. Pecor; J.A. Stoffer \& T. ANDERSON. 2012. Systematic Catalog of Culicidae. Suitland, Walter Reed Biosystematics Unit. Available online at: www.mosquitocatalog.org [Accessed: 02/VII/2012]

Galindo, P. \& S. SRIHOngSe. 1967. Transmission of arboviruses to hamsters by the bite of naturally infected Culex (Melanoconion) mosquitoes. American Journal of Tropical Medicine and Hygiene 16 (4): 525-530.

Galindo, P.; S. Srihongse; E. de Rodaniche \& M.A. Grayson. 1966. An ecological survey for arboviruses in Almirante, Panama, 1959-1962. American Journal of Tropical Medicine and Hygiene 15 (3): 385-400. 
HarbaCH, R.E. 2012. Family Culicidae Meigen, 1818. In: Mosquito Taxonomic Inventory. Available online at: http:// mosquito-taxonomic-inventory.info/family-culicidaemeigen-1818 [Accessed: 11/VIII/2012]

Hutchings, R.S.G.; R.W. Hutchings \& M.A.M. Sallum. 2010. Culicidae (Diptera: Culicomorpha) from the Western Brazilian Amazon: Juami-Japurá Ecological Station. Revista Brasileira de Entomologia 54 (4): 687-691. doi: 10.1590/ S0085-56262010000400022.

Hutchings, R.S.G. \& M.A.M. SAllum. 2008. Two new species of Culex subgenus Melanoconion (Diptera: Culicidae) from the Amazon forest. Zootaxa 1920: 41-50.

Hutchings, R.S.G.; M.A.M. Sallum \& R.L.M. Ferreira. 2002. Culicidae (Diptera: Culicomorpha) da Amazônia ocidental Brasileira: Querari. Acta Amazonica 32 (1): 109-122.

Hutchings, R.S.G.; M.A.M. Sallum; R.L.M. Ferreira \& R.W. Hutchings. 2005. Mosquitoes of the Jaú National Park and their potential importance in Brazilian Amazonia. Medical and Veterinary Entomology 19 (4): 428-441. doi: 10.1111/ j.1365-2915.2005.00587.x.

Hutchings, R.S.G.; M.A.M. Sallum \& R.W. Hutchings. 2011. Mosquito (Diptera: Culicidae) diversity of a forest-fragment mosaic in the Amazon rainforest. Journal of Medical Entomology 48 (2): 173-187. doi: 10.1603/ME10061.

Hutchings, R.W.; R.S.G. Hutchings \& M.A.M. Sallum. 2008. Distribuição de Culicidae na várzea, ao longo da calha dos Rios Solimões-Amazonas, p. 133-152. In: Conservação da várzea: Identificação e caracterização de regiões biogeográficas. A.L.K.M. Albernaz (Ed.). Manaus, IBAMA, ProVárzea.

LANE, J. 1953a. Neotropical Culicidae: Dixinae, Chaoborinae and Culicinae; Tribes Anophelini, Toxorhynchitini and Culicini (Genus Culex only). São Paulo, Universidade de São Paulo, vol. 1, 548p.

LANE, J. 1953b. Neotropical Culicidae: Tribe Culicini Deinocerites, Uranotaenia, Mansonia, Orthopodomyia, Aedomyia, Aedes, Psorophora, Haemagogus; Tribe Sabethini - Trichoprosopon, Wyeomyia, Phoniomyia, Limatus and Sabethes. São Paulo, Universidade de São Paulo, vol. 2, 558p.

Мотокі, M.T.; C.L.S.D. Santos \& M.A.M. SAllum. 2009. Intraespecific variation on the aedeagus of Anopheles oswaldoi (Peryassú) (Diptera: Culicidae). Neotropical Entomology 38: 144-148. doi: 10.1590/S1519-566X2009000100017.

Pecor, J.E.; V.L. Mallampalli; R.E. Harbach \& E.L. Peyton. 1992. Catalog and illustrated review of the subgenus Melanoconion of Culex (Diptera: Culicidae). Contributions of the American Entomological Institute 27 (2): 1-228.

RADAMBRASIL. 1976. Folha SA. 21 Santarem; geologia, geomorfologia, pedologia, vegetação e uso potencial da terra. Rio de Janeiro, Departamento Nacional de Produção Mineral, Projeto RADAM, 522p.

Sallum, M.A.M. \& O.P. Forattint. 1996. Revision of the Spissipes Section of Culex (Melanoconion) (Diptera: Culicidae). Journal of the American Mosquito Control Association 12 (3): 517-600.
Sallum, M.A.M. \& R.S.G. Hutchings. 2003. Taxonomic studies on Culex (Melanoconion) coppenamensis Bonne-Wepster \& Bonne (Diptera: Culicidae), and description of two new species from Brazil. Memórias do Instituto Oswaldo Cruz 98 (5): 615-622. doi: 10.1590/S0074-02762003000500006.

Sallum, M.A.M.; R.S.G. Hutchings \& R.L.M. Ferreira. 1997. Culex gnomatos a new species of the Spissipes section of Culex (Melanoconion) (Diptera: Culicidae) from the Amazon Region. Memórias do Instituto Oswaldo Cruz 92 (2): 215219. doi: 10.1590/S0074-02761997000200014.

SAllum, M.A.M.; M.T. Marrelli; S.S. NAGaKi; G.Z. Laporta \& C.L.S. Dos SAntos. 2008. Insight into Anopheles (Nyssorhynchus) (Diptera: Culicidae) species from Brazil. Journal of Medical Entomology 45 (6): 970-981.

Shope, R.E.; J.P. Woodhall \& A.T.D. Rosa. 1988. The epidemiology of diseases caused by viruses in Groups C and Guama (Bunyaviridae), p. 37-52. T.P. Monath (Ed.). In: The Arboviruses: epidemiology and ecology. Boca Raton, CRC Press, vol. 3.

SRIHONGSE, S. \& P. GaLIndo. 1967. The isolation of eastern equine encephalitis virus from Culex (Melanoconion) taeniopus Dyar and Knab in Panama. Mosquito News 27: 74-76.

SuÁreZ-Mutis, M.C.; N.F. Fé; W. Alecrim \& J.R. Coura. 2009. Night and crepuscular mosquitoes and risk of vector-borne diseases in areas of piassaba extraction in the middle Negro River basin, state of Amazonas, Brazil. Memórias do Instituto Oswaldo Cruz 104 (1): 11-17. doi: 10.1590/S007402762009000100002.

Turell, M.J.; J.W. Jones; M.R. Sardelis; D.J. Dohm; R.E. Coleman; D.M. Watts; R. Fernandez; C. Calampa \& T.A. Klein. 2000. Vector competence of Peruvian mosquitoes (Diptera: Culicidae) for epizootic and enzootic strains of Venezuelan equine encephalomyelitis virus. Journal of Medical Entomology 37 (6): 835-839.

Valencia, J.D. 1973. Mosquito Studies (Diptera, Culicidae). 31. A revision of the Subgenus Carrollia of Culex. Contributions of the American Entomological Institute 9 (4): 1-133.

Walton, T.E. \& M.A. Grayson. 1988. Venezuelan equine encephalomyelitis, p. 203-231. In: The Arboviruses: epidemiology and ecology. T.P. MONATH (Ed.). Boca Raton, CRC Press, vol. 4.

Xavier, S.H. \& S.D.S. Mattos. 1976. Geographical distribution of Culicinae in Brazil. 4. State of Amazonas (Diptera, Culicidae). Mosquito Systematics 8 (4): 386-412.

Zavortink, T.J. 1972. Mosquito Studies (Diptera, Culicidae). 28. The New World species formerly placed in Aedes (Finlaya). Contributions of the American Entomological Institute 8 (3): 1-206.

Zavortink, T.J. 1979. Mosquito Studies (Diptera, Culicidae). 35. The new Sabethine genus Johnbelkinia and a preliminary reclassification of the composite genus Trichoprosopon. Contributions of the American Entomological Institute 17 (1): 1-61. 
Appendix 1. Mosquito species collected along the Nhamundá and Abacaxis Rivers, Amazonas, Brazil.

\begin{tabular}{|c|c|c|c|c|c|c|c|c|c|c|c|}
\hline \multirow[b]{2}{*}{ Taxa } & \multirow[b]{2}{*}{ Number a } & \multicolumn{2}{|c|}{ River } & \multirow[b]{2}{*}{ Sex ${ }^{b}$} & \multicolumn{7}{|c|}{ Method of Capture ${ }^{c}$} \\
\hline & & Nhamundá & Abacaxis & & Ů & 苩 & 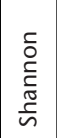 & 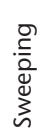 & $\frac{\frac{\mathscr{m}}{\pi}}{\frac{\pi}{\frac{\pi}{N}}}$ & $\begin{array}{l}\frac{\partial}{d} \\
\frac{0}{0} \\
\bar{\nu} \\
\frac{0}{n} \\
\bar{n}\end{array}$ & 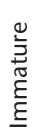 \\
\hline \multicolumn{12}{|l|}{ Anophelinae } \\
\hline \multicolumn{12}{|l|}{ Anopheles } \\
\hline \multicolumn{12}{|l|}{ (Anopheles) } \\
\hline eiseni Coquillett, 1902 & 1 & & 1 & $\mathrm{~F}$ & & & & & $x$ & & \\
\hline forattinii Wilkerson \& Sallum, 1999 & 21 & 2 & 19 & $20 \mathrm{~F}+\mathrm{Mgen}$ & 3 & 5 & 13 & & & & \\
\hline mattogrossensis Lutz \& Neiva, 1911 & 2 & & 2 & $\mathrm{~F}$ & & 1 & 1 & & & & \\
\hline peryassui Dyar \& Knab, 1908 & 1 & & 1 & $\mathrm{~F}$ & & & $x$ & & & & \\
\hline shannoni Davis, 1931 & 5 & 1 & 4 & $\mathrm{~F}$ & 2 & 1 & 2 & & & & \\
\hline (Anopheles) sp. & 7 & & 7 & $\mathrm{~F}$ & & & & & & & \\
\hline \multicolumn{12}{|l|}{ (Nyssorhynchus) } \\
\hline goeldii Rozeboom \& Gabaldon, 1941 & 1 & & 1 & Mgen & & $x$ & & & & & \\
\hline konderi s.l. & 7 & & 7 & $\mathrm{~F}$ & 4 & 3 & & & & & \\
\hline oswaldoi s.l. & 26 & 2 & 24 & $\mathrm{~F}$ & 5 & 19 & 2 & & & & \\
\hline triannulatus (Neiva \& Pinto, 1922) & 2 & 1 & 1 & Mgen+F & 1 & & & 1 & & & \\
\hline goeldii / dunhami ${ }^{\mathrm{d}}$ & 3 & 2 & 1 & $\mathrm{~F}$ & & & & & & & \\
\hline konderi / oswaldoi d & 1 & & 1 & Fdam & & & & & & & \\
\hline (Nyssorhynchus) sec. Albimanus & 1 & & 1 & Fdam & & & & & & & \\
\hline (Nyssorhynchus) sp. & 27 & & 27 & Fdam & & & & & & & \\
\hline \multicolumn{12}{|l|}{ (Stethomyia) } \\
\hline canorii Floch \& Abonnenc, 1945 & 2 & & 2 & Mgen & 1 & & & 1 & & & \\
\hline kompi Edwards, 1930 & 8 & 1 & 7 & $\mathrm{~F}$ & 5 & 1 & 2 & & & & \\
\hline nimbus (Theobald, 1902) & 10 & 4 & 6 & $9 M G e n+F$ & & & & 7 & 2 & & 1 \\
\hline thomasi Shannon, 1933 & 2 & & 2 & Mgen & & $x$ & & & & & \\
\hline nimbus / thomasi d & 33 & 15 & 18 & $\mathrm{~F}$ & & & & & & & \\
\hline Anopheles sp. & 6 & 2 & 4 & 4Fdam+2Mdam & & & & & & & \\
\hline Total Anopheles & 166 & 30 & 136 & & & & & & & & \\
\hline \multicolumn{12}{|l|}{ Culicinae } \\
\hline \multicolumn{12}{|l|}{ Aedeomyiini } \\
\hline \multicolumn{12}{|l|}{ Aedeomyia } \\
\hline \multicolumn{12}{|l|}{ (Aedeomyia) } \\
\hline squamipennis (Lynch Arribalzaga, 1878) & 6 & 1 & 5 & $\mathrm{~F}$ & 5 & & & & & & 1 \\
\hline Total Aedeomyia & 6 & 1 & 5 & & & & & & & & \\
\hline \multicolumn{12}{|l|}{ Aedini } \\
\hline \multicolumn{12}{|l|}{ Haemagogus } \\
\hline \multicolumn{12}{|l|}{ (Haemagogus) } \\
\hline baresi Cerqueira, 1960 & 2 & & 2 & $\mathrm{~F}$ & & & & $x$ & & & \\
\hline janthinomys Dyar, 1921 & 1 & & 1 & Mgen & & & & $x$ & & & \\
\hline Haemagogus sp. & 1 & 1 & & Fdam & & & & & & & \\
\hline Total Haemagogus & 4 & 1 & 3 & & & & & & & & \\
\hline \multicolumn{12}{|l|}{ Aedes } \\
\hline (Howardina) & & & & & & & & & & & \\
\hline arborealis Bonne-Wepster \& Bonne, 1919 & 1 & & 1 & $\mathrm{~F}$ & & & & $x$ & & & \\
\hline fulvithorax (Lutz, 1904) & 1 & 1 & & $\mathrm{~F}$ & & & & & $x$ & & \\
\hline
\end{tabular}


Appendix 1. Continued.

\begin{tabular}{|c|c|c|c|c|c|c|c|c|c|c|c|}
\hline \multirow[b]{2}{*}{ Taxa } & \multirow[b]{2}{*}{ Number $^{\mathrm{a}}$} & \multicolumn{2}{|c|}{ River } & \multirow[b]{2}{*}{ Sex ${ }^{b}$} & \multicolumn{7}{|c|}{ Method of Capture $^{c}$} \\
\hline & & Nhamundá & Abacaxis & & U๖ & & $\begin{array}{l}\frac{c}{O} \\
\frac{c}{c} \\
\frac{c}{D} \\
\frac{c}{n}\end{array}$ & $\begin{array}{l}0 \\
\frac{5}{2} \\
\frac{0}{2} \\
\frac{0}{3} \\
n\end{array}$ & $\frac{\sqrt[n]{\frac{N}{N}}}{\frac{\pi}{N}}$ & & 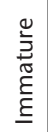 \\
\hline $\begin{array}{l}\text { (Ochlerotatus) } \\
\text { fulvus (Wiedemann, 1828) } \\
\text { oligopistus Dyar, 1918 } \\
\text { rhyacophilus (Costa Lima, 1933) } \\
\text { scapularis (Rondani, 1848) } \\
\text { serratus (Theobald, 1901) } \\
\text { near pectinatus } \mathrm{F}^{\mathrm{e}} \\
\text { near sG Infirmatus } \mathrm{F}^{\mathrm{e}} \\
\text { hastatus / oligopistus }{ }^{\mathrm{d}} \\
\text { serratus / nubilus }{ }^{\mathrm{d}} \\
\text { (Ochlerotatus) sG Infirmatus } \\
\text { (Ochlerotatus) sp. } \\
\text { (Protomacleaya) } \\
\text { argyrothorax Bonne-Wepster \& Bonne, } 1919 \\
\text { Aedes sp. } \\
\text { Total Aedes }\end{array}$ & $\begin{array}{c}17 \\
1 \\
15 \\
5 \\
5 \\
3 \\
1 \\
1 \\
10 \\
25 \\
2 \\
2 \\
1 \\
90\end{array}$ & $\begin{array}{l}12 \\
2 \\
5 \\
2 \\
1 \\
1 \\
5 \\
16 \\
\\
45\end{array}$ & $\begin{array}{c}5 \\
1 \\
13 \\
3 \\
3 \\
3 \\
\\
5 \\
9 \\
2 \\
2 \\
1 \\
45 \\
\end{array}$ & $\begin{array}{c}\text { Mgen+16F } \\
\mathrm{F} \\
\text { 14F+Mgen } \\
\mathrm{F} \\
\text { 3F+2Mgen } \\
\text { Mgen } \\
\text { Mgen } \\
\text { Fdam } \\
\text { Fdam } \\
\text { F } \\
\text { Fdam } \\
\text { Mgen+F } \\
\text { Fdam }\end{array}$ & $\begin{array}{r}5 \\
\times \\
1\end{array}$ & $\begin{array}{l}2 \\
1 \\
1\end{array}$ & 4 & $\begin{array}{c}12 \\
3 \\
3 \\
x\end{array}$ & & & \\
\hline $\begin{array}{l}\text { Psorophora } \\
\text { (Grabhamia) } \\
\text { dimidiata Cerqueira, 1943 } \\
\text { (Janthinosoma) } \\
\text { albigenu (Peryassú, 1908) } \\
\text { albipes (Theobald, 1907) } \\
\text { amazonica Cerqueira, 1960 } \\
\text { circumflava Cerqueira, 1943 } \\
\text { discrucians (Walker, 1856) } \\
\text { ferox (Humboldt, 1819) } \\
\text { (Psorophora) } \\
\text { ciliata (Fabricius, 1794) } \\
\text { cilipes (Fabricius, 1805) } \\
\text { Psorophora sp. } \\
\text { Total Psorophora }\end{array}$ & $\begin{array}{c}3 \\
\\
35 \\
13 \\
49 \\
1 \\
2 \\
44 \\
\\
1 \\
1 \\
29 \\
178\end{array}$ & $\begin{array}{c}3 \\
\\
3 \\
5 \\
10 \\
\\
2 \\
38 \\
\\
1 \\
9 \\
71\end{array}$ & $\begin{array}{c}32 \\
8 \\
39 \\
1 \\
6 \\
1 \\
107\end{array}$ & $\begin{array}{c}\mathrm{F} \\
\mathrm{F} \\
\mathrm{F} \\
47 \mathrm{~F}+2 \mathrm{Mgen} \\
\mathrm{F} \\
\text { Mgen } \\
\text { 35Mgen+9F } \\
\text { F } \\
\text { Mgen } \\
\text { 28Fdam+Mdam }\end{array}$ & $\begin{array}{l}9 \\
2 \\
8 \\
x \\
1\end{array}$ & $\begin{array}{c}4 \\
3 \\
10\end{array}$ & $\begin{array}{l}1 \\
1\end{array}$ & $\begin{array}{c}21 \\
7 \\
30 \\
x \\
38\end{array}$ & 1 & 4 & \\
\hline $\begin{array}{l}\text { Culicini } \\
\text { Culex } \\
\qquad \begin{array}{l}\text { (Aedinus) } \\
\text { accelerans Root, } 1927 \\
\text { amazonensis (Lutz, 1905) } \\
\text { guyanensis Clastrier, 1970 } \\
\text { clastrieri / guyanensis d } \\
\text { (Aedinus) sp. } \\
\text { (Anoedioporpa) } \\
\text { luteopleurus (Theobald, 1903) }{ }^{\text {e }} \\
\text { originator Gordon \& Evans, 1922 } \\
\text { (Anoedioporpa) sp. }\end{array}\end{array}$ & $\begin{array}{c}2 \\
5 \\
1 \\
4 \\
3 \\
\\
1 \\
2 \\
10\end{array}$ & $\begin{array}{l}1 \\
2 \\
1\end{array}$ & $\begin{array}{l}1 \\
3 \\
1 \\
3 \\
3\end{array}$ & $\begin{array}{c}F \\
F \\
F \\
F \\
\text { Fdam } \\
\text { F } \\
\text { Mgen+F } \\
\text { Fdam }\end{array}$ & 1 & $\begin{array}{l}1 \\
1\end{array}$ & & $\begin{array}{l}3 \\
x\end{array}$ & & $x$ & \\
\hline
\end{tabular}




\begin{tabular}{|c|c|c|c|c|c|c|c|c|c|c|c|}
\hline \multirow[b]{2}{*}{ Taxa } & \multirow[b]{2}{*}{ Number ${ }^{a}$} & \multicolumn{2}{|c|}{ River } & \multirow[b]{2}{*}{ Sex ${ }^{b}$} & \multicolumn{7}{|c|}{ Method of Capture ${ }^{c}$} \\
\hline & & Nhamundá & Abacaxis & & U & 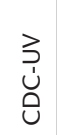 & 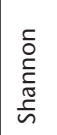 & 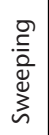 & 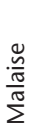 & $\begin{array}{l}\frac{\partial}{d} \\
\frac{0}{0} \\
\bar{d} \\
\frac{0}{n} \\
\tilde{n}\end{array}$ & 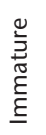 \\
\hline (Carrollia) & & & & & & & & & & & \\
\hline urichii (Coquillett, 1906) & 5 & 5 & & $3 \mathrm{~F}+2 \mathrm{Mgen}$ & & & & & & & $x$ \\
\hline urichii / anduzei ${ }^{d}$ & 2 & 2 & & $\mathrm{~F}$ & & & & & & & \\
\hline (Carrollia) sp. & 1 & & 1 & Fdam & & & & & & & \\
\hline (Culex) & & & & & & & & & & & \\
\hline bidens Dyar, 1922 & 1 & 1 & & $\mathrm{~F}$ & & & $x$ & & & & \\
\hline chidesteri Dyar, 1921 & 2 & & 2 & $\mathrm{~F}$ & & $\mathrm{x}$ & & & & & \\
\hline declarator Dyar \& Knab, 1906 & 255 & 10 & 245 & $245 \mathrm{~F}+$ Mgen & 163 & 82 & 10 & & & & \\
\hline dolosus Lynch Arribalzaga, 1891 & 1 & & 1 & $\mathrm{~F}$ & $x$ & & & & & & \\
\hline mollis Dyar \& Knab, 1906 & 456 & 29 & 427 & $450 \mathrm{~F}+6 \mathrm{Mgen}$ & 275 & 165 & 10 & 4 & 1 & 1 & \\
\hline usquatissimus Dyar, 1922 & 1 & & 1 & Mgen & & & & $x$ & & & \\
\hline coronator / usquatus ${ }^{d}$ & 36 & 19 & 17 & $\mathrm{~F}$ & & & & & & & \\
\hline mollis / declarator ${ }^{\mathrm{d}}$ & 3 & 3 & & Fdam & & & & & & & \\
\hline (Culex) gr. Coronator & 17 & & 17 & $\mathrm{~F}$ & & & & & & & \\
\hline (Culex) sp. & 245 & 8 & 237 & 243Fdam+2Mdam & & & & & & & \\
\hline (Melanoconion) & & & & & & & & & & & \\
\hline adamesi Sirivanakarn \& Galindo, 1980 & 2 & & 2 & $\mathrm{~F}$ & $x$ & & & & & & \\
\hline alogistus Dyar, 1918 & 3 & & 3 & Mgen & 1 & 2 & & & & & \\
\hline bequaerti Dyar \& Shannon, 1925 & 77 & 64 & 13 & $48 \mathrm{~F}+29 \mathrm{Mgen}$ & 10 & 52 & 13 & 2 & & & \\
\hline brachiatus Hutchings \& Sallum, $2008^{\dagger}$ & 1 & & 1 & Mgen & & $x$ & & & & & \\
\hline caudatus Clastrier, 1970 & 8 & & 8 & Mgen & & 5 & 3 & & & & \\
\hline caudelli (Dyar \& Knab, 1906) & 24 & 22 & 2 & Mgen & 2 & 16 & 3 & 3 & & & \\
\hline clarki Evans, 1924 & 4 & & 4 & $\mathrm{~F}$ & & 2 & 2 & & & & \\
\hline comatus Sénevet \& Abonnenc, 1939 & 1 & 1 & & Mgen & & $x$ & & & & & \\
\hline coppenamensis Bonne-Wepster \& Bonne, 1919 & 4 & & 4 & Mgen & 1 & 3 & & & & & \\
\hline corentynensis Dyar, 1920 & 1 & & 1 & Mgen & $x$ & & & & & & \\
\hline crybda Dyar, 1924 & 13 & & 13 & $\mathrm{~F}$ & 8 & 4 & 1 & & & & \\
\hline dolichophyllus Clastrier, 1970 & 3 & 1 & 2 & $2 \mathrm{~F}+$ Mgen & 1 & 1 & 1 & & & & \\
\hline eastor Dyar, 1920 & 4 & & 4 & Mgen & 1 & 2 & 1 & & & & \\
\hline eknomios Forattini \& Sallum, 1992 & 481 & 2 & 479 & $468 \mathrm{~F}+13 \mathrm{Mgen}$ & 309 & 154 & 4 & 14 & & & \\
\hline fairchildi Galindo \& Blanton, 1954 & 9 & 3 & 6 & Mgen & 2 & 3 & 4 & & & & \\
\hline foliafer Komp \& Rozeboom, 1951 & 1 & 1 & & Mgen & & $x$ & & & & & \\
\hline gnomatos Sallum, Hutchings \& Ferreira, 1997 & 124 & & 124 & $\mathrm{~F}$ & 82 & 40 & 1 & & 1 & & \\
\hline innovator Evans, 1924 & 3 & 3 & & Mgen & 1 & 1 & 1 & & & & \\
\hline johnsoni Galindo \& Mendez, 1961 & 24 & & 24 & $19 \mathrm{Mgen}+5 \mathrm{~F}$ & 9 & & 15 & & & & \\
\hline pedroi Sirivanakarn \& Belkin, 1980 & 6 & 3 & 3 & $5 F+$ Mgen & 2 & 3 & & & & 1 & \\
\hline phyllados Hutchings \& Sallum, $2008^{\mathrm{f}, \mathrm{g}}$ & 15 & 5 & 10 & Mgen & 2 & 9 & 2 & 2 & & & \\
\hline pilosus (Dyar \& Knab, 1906) & 5 & 4 & 1 & Mgen & 1 & 1 & 1 & 1 & 1 & & \\
\hline portesi Senevet \& Abonnenc, 1941 & 3 & & 3 & $\mathrm{~F}$ & $x$ & & & & & & \\
\hline putumayensis Matherson, 1934 & 1 & 1 & & Mgen & & & & $x$ & & & \\
\hline rooti Rozeboom, 1935 e & 2 & 1 & 1 & Mgen & & & 1 & 1 & & & \\
\hline spissipes (Theobald, 1903) & 91 & 4 & 87 & $88 \mathrm{~F}+3 \mathrm{Mgen}$ & 77 & 7 & 2 & 5 & & & \\
\hline symbletos Sallum \& Hutchings, 2003 & 5 & 1 & 4 & Mgen & 1 & 2 & & 2 & & & \\
\hline
\end{tabular}


Appendix 1. Continued.

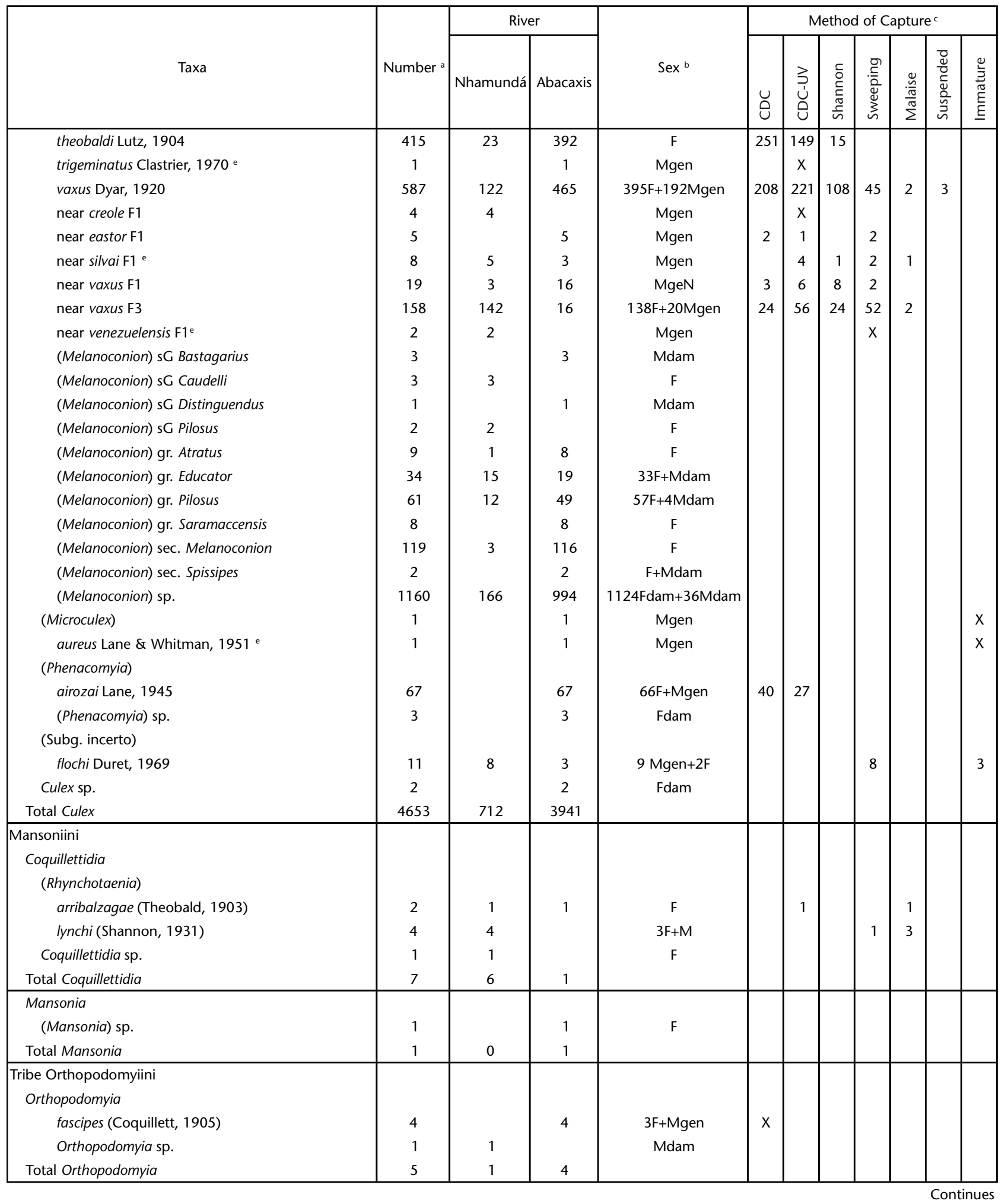


Appendix 1. Continued.

\begin{tabular}{|c|c|c|c|c|c|c|c|c|c|c|c|}
\hline \multirow[b]{2}{*}{ Taxa } & \multirow[b]{2}{*}{ Number ${ }^{a}$} & \multicolumn{2}{|c|}{ River } & \multirow[b]{2}{*}{ Sex ${ }^{b}$} & \multicolumn{7}{|c|}{ Method of Capture ${ }^{c}$} \\
\hline & & Nhamundá & Abacaxis & & U & ذ̇ & 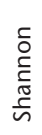 & 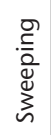 & $\frac{\frac{n}{\pi}}{\frac{\pi}{n}}$ & $\begin{array}{l}\frac{0}{d} \\
\frac{0}{0} \\
\frac{c}{0} \\
\frac{0}{n} \\
\stackrel{0}{n}\end{array}$ & 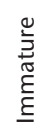 \\
\hline 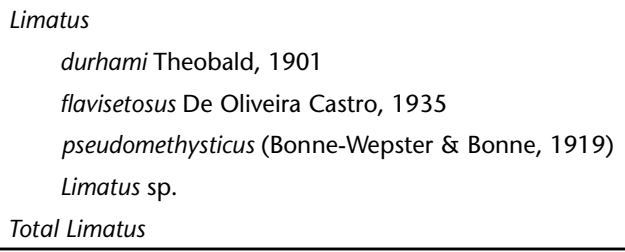 & $\begin{array}{l}1 \\
1 \\
4 \\
3 \\
9\end{array}$ & $\begin{array}{l}1 \\
2 \\
3 \\
6\end{array}$ & $\begin{array}{l}1 \\
2 \\
3\end{array}$ & $\begin{array}{c}F \\
F \\
F \\
\text { Fdam }\end{array}$ & & & & $\begin{array}{l}x \\
x \\
1\end{array}$ & 2 & 1 & \\
\hline $\begin{array}{l}\text { Onirion } \\
\qquad \text { brucei (Del Ponte \& Cerqueira, 1938) }{ }^{\text {e }} \\
\text { Total Onirion }\end{array}$ & $\begin{array}{l}1 \\
1\end{array}$ & $\begin{array}{l}1 \\
1\end{array}$ & 0 & & & & & & & & $x$ \\
\hline $\begin{array}{l}\text { Sabethes } \\
\text { (Sabethes) } \\
\text { amazonicus Gordon \& Evans, } 1922 \\
\text { cyaneus (Fabricius, 1805) } \\
\text { spixi Cerqueira, 1961 } \\
\text { (Sabethoides) } \\
\text { glaucodaemon (Dyar \& Shannon, 1925) } \\
\text { tridentatus Cerqueira, 1961 } \\
\text { (Sabethoides) sp. } \\
\text { Sabethes sp. } \\
\text { Total Sabethes }\end{array}$ & $\begin{array}{c}2 \\
1 \\
4 \\
4 \\
3 \\
5 \\
2 \\
21\end{array}$ & $\begin{array}{c}1 \\
1 \\
2 \\
2 \\
2 \\
2 \\
1 \\
11\end{array}$ & $\begin{array}{c}1 \\
2 \\
2 \\
1 \\
3 \\
1 \\
10\end{array}$ & $\begin{array}{c}\mathrm{F} \\
\mathrm{F} \\
3 \mathrm{~F}+\mathrm{M} \\
\mathrm{F} \\
\mathrm{F} \\
\text { 4F+Mgen } \\
\text { Fdam }\end{array}$ & & & & $x$ & 2 & $x$ & \\
\hline $\begin{array}{l}\text { Trichoprosopon } \\
\quad \text { digitatum (Rondani, 1848) } \\
\quad \text { Trichoprosopon sp. } \\
\text { Total Trichoprosopon }\end{array}$ & $\begin{array}{l}8 \\
1 \\
9\end{array}$ & $\begin{array}{l}2 \\
2\end{array}$ & $\begin{array}{l}6 \\
1 \\
7\end{array}$ & $\begin{array}{c}5 \mathrm{~F}+3 \mathrm{Mgen} \\
\text { Fdam }\end{array}$ & & 1 & & 2 & 4 & 1 & \\
\hline $\begin{array}{l}\text { Wyeomyia } \\
\text { (Cruzmyia) } \\
\text { kummi Lane \& Cerqueira, } 1942 \\
\text { (Dendromyia) } \\
\text { testei Senevet \& Abonnenc, } 1939 \\
\text { ypsipola Dyar, } 1922 \\
\text { (Dodecamyia) } \\
\text { aphobema Dyar, } 1918 \\
\text { (Exallomyia) } \\
\text { tarsata Lane \& Cerqueira, } 1942 \\
\text { (Hystatomyia) } \\
\text { near baltae F1 e } \\
\text { (Hystatomyia) sp. } \\
\text { (Phoniomyia) } \\
\text { splendida (Bonne-Wepster \& Bonne, 1919) } \\
\text { (Phoniomyia) sp. } \\
\text { (Spilonympha) } \\
\text { aningae Motta \& Lourenço, 2005 e }\end{array}$ & $\begin{array}{l}3 \\
7 \\
2 \\
2 \\
1 \\
1\end{array}$ & $\begin{array}{l}1 \\
2 \\
1 \\
3 \\
6 \\
2 \\
1 \\
1 \\
1\end{array}$ & 1 & $\begin{array}{c}F \\
\text { Mgen+F } \\
F \\
\text { Mgen } \\
\text { 6F+M } \\
\text { Mgen } \\
\text { Mgen+F } \\
\text { Mgen } \\
F \\
F\end{array}$ & & & $X$ & $\begin{array}{l}1 \\
2\end{array}$ & 4 & $\begin{array}{l}1 \\
1\end{array}$ & $x$ \\
\hline
\end{tabular}


Appendix 1. Continued.

\begin{tabular}{|c|c|c|c|c|c|c|c|c|c|c|c|}
\hline \multirow[b]{2}{*}{ Taxa } & \multirow[b]{2}{*}{ Number ${ }^{a}$} & \multicolumn{2}{|c|}{ River } & \multirow[b]{2}{*}{$\operatorname{Sex}{ }^{b}$} & \multicolumn{7}{|c|}{ Method of Capture ${ }^{c}$} \\
\hline & & Nhamundá & Abacaxis & & 巳ั & $\begin{array}{l}3 \\
\text { ù }\end{array}$ & 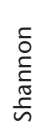 & $\begin{array}{l}\text { o } \\
. \frac{\Xi}{0} \\
\frac{0}{0} \\
\sum_{n}^{0}\end{array}$ & $\frac{\frac{\pi}{N}}{\frac{\pi}{N}}$ & $\begin{array}{l}0 \\
\frac{0}{0} \\
\frac{0}{0} \\
\frac{0}{d} \\
\frac{0}{n} \\
\tilde{n}\end{array}$ & 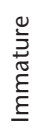 \\
\hline (Subg. incerto) & & & & & & & & & & & \\
\hline aporonoma Dyar \& Knab, 1906 & 5 & 4 & 1 & $\mathrm{~F}$ & & & & 3 & & 2 & \\
\hline argenteorostris Bonne-Wepster \& Bonne, 1919 & 2 & 1 & 1 & $\mathrm{~F}$ & & & & & $x$ & & \\
\hline flui Bonne-Wepster \& Bonne, 1919 & 2 & 1 & 1 & Mgen & & & & 1 & & 1 & \\
\hline surinamensis Bruijning, $1959^{\text {e }}$ & 1 & 1 & & Mgen & & & & & $x$ & & \\
\hline prox. moerbista & 2 & 2 & & $\mathrm{~F}$ & & & & 1 & 1 & & \\
\hline gr. Flui & 1 & 1 & & Mgen & & & & & & & \\
\hline Wyeomyia sp. & 8 & 5 & 3 & $7 F+M$ & & & & & & & \\
\hline \multicolumn{12}{|l|}{ Uranotaeniini } \\
\hline \multirow{2}{*}{\multicolumn{12}{|c|}{$\begin{array}{l}\text { Uranotaenia } \\
\qquad \text { (Uranotaenia) }\end{array}$}} \\
\hline & & & & & & & & & & & \\
\hline apicalis Theobald, 1903 & 5 & 4 & 1 & $\mathrm{~F}$ & 1 & 4 & & & & & \\
\hline ditaenionota Prado, 1931 & 1 & & 1 & $\mathrm{~F}$ & & $x$ & & & & & \\
\hline geometrica Theobald, 1901 & 4 & & 4 & $\mathrm{~F}$ & 1 & 3 & & & & & \\
\hline lowii Theobald, 1901 & 3 & & 3 & $\mathrm{~F}$ & & $\mathrm{X}$ & & & & & \\
\hline pallidoventer Theobald, 1903 & 1 & 1 & & $\mathrm{~F}$ & & $x$ & & & & & \\
\hline pulcherrima Lynch Arribalzaga, 1891 & 18 & 1 & 17 & $12 \mathrm{~F}+6 \mathrm{M}$ & 2 & 14 & 1 & & & 1 & \\
\hline (Uranotaenia) sp. & 5 & & 5 & Fdam & & & & & & & \\
\hline Total Uranotaenia & 37 & 6 & 31 & & & & & & & & \\
\hline \multicolumn{12}{|l|}{ Toxorhynchitinae } \\
\hline \multicolumn{12}{|l|}{ Toxorhynchitini } \\
\hline (Lynchiella) & & & & & & & & & & & \\
\hline haemorrhoidalis (Fabricius, 1787) & 1 & & 1 & $\mathrm{~F}$ & & & & & & $x$ & \\
\hline Toxorhynchites sp. & 1 & 1 & & Mgen & & & & & & & \\
\hline Total Toxorhynchites & 2 & 1 & 1 & & & & & & & & \\
\hline Number of mosquitoes identified & 5231 & 928 & 4303 & $4610 \mathrm{~F}+621 \mathrm{M}$ & & & & & & & \\
\hline Specimens not identified ${ }^{\mathrm{h}}$ & 59 & 5 & 54 & & & & & & & & \\
\hline Total number of specimens & 5290 & 933 & 4357 & & & & & & & & \\
\hline
\end{tabular}

a Indicates the total number of specimens for each taxon.

${ }^{b}$ Indicates the sex and/or condition of the specimens collected: $M=$ male; $F=$ female; dam = damaged specimen; gen = identified using genitalia dissection.

c $\mathrm{X}=$ specimens of the taxon were only captured using this method.

${ }^{d}$ It was not possible to identify these specimens to species level because either there are no known characters which can be used to separate the females of these two species, or the characters used to separate these species are damaged.

e First published record for the state of Amazonas.

${ }^{f}$ First geographical range extension for this species since it was described (Hutchincs \& SALLum 2008).

9 Includes a paratype of this species ((HutchinGs \& SAlLum 2008).

${ }^{\mathrm{h}}$ Includes either immature specimens which died during the rearing process or adult specimens which were damaged during the mounting process.

Submitted: 29.VIII.2012; Accepted: 02.XII.2012.

Editorial responsibility: Gabriel L.F. Mejdalani 